best," which did not do in these days. Dr. H. GoRdoN thought Dr. HarveySmith had done a great service not only to hospital junior staff but to the whole profession. The Organization Committee should also consider the position in the B.M.A. of young doctors in all branches of medicine. Was their place in the negotiating machinery satisfactory?

\section{Regional Organization}

Dr. R. A. A. R. LAwrence thought that the regional organization of hospital junior staff was the most difficult part of the problem. If that could be worked out, and they had efficient and skilled men to represent them, many of the difficulties would be solved.
Dr. A. B. Gilmour saw that there were technical difficulties in making the H.J.S. Group Committee a standing committee, but he thought that hospital junior doctors were a special group in a class of their own. He wondered whether a special formula could not be devised for giving them the status of an independent committee as an interim measure while Dr. Potter's suggestion was considered. Dr. C. C. LutTon was against making the H.J.S. Group Committee a standing committee. The blame for the current difficulties was fairly and squarely on the shoulders of the senior men, who had not interested themselves in their junior staff.

Dr. H. C. W. BAKER also supported an alteration in the C.C. and S. Committee's name to Hospital Services Committee, and he added that junior staff should be properly represented on it.

It was agreed to recommend to the Council that the Central Consultants and Specialists Committee should be invited to consider altering its name to "Hospital Services Committee" in view of the fact that the majority of the doctors they represented were not consultants.

It was also recommended that regional conferences should be called periodically to disseminate information and to discuss the problems of hospital junior staff.

\section{Association Membership}

The Chairman reported that the B.M.A membership was 68,064 , as compared with 68,034 at the same time last year.

\section{Association Notices}

\section{Diary of Central Meetings}

\section{FEBRUARY}

15 Tues. Committee on Therapeutic Abortion, 12 noon.

16 Wed. Council, 10 a.m.

17 Thurs. General Medical Services Committee, 10.30 a.m.

17 Thurs. G.M.S. Liaison Committee with the College of Genera Practitioners, 5.30 p.m

18 Fri. Age of Majority Evidence Committee, 10.30 a.m.

18 Fri. Subcommitlee on Area Health Boards (Welsh Committee) (at Welsh Regional Office, 195 Newport Road, Cardiff), 12 noon.

18 Fri. Committee on the Mental Health Act, 2 p.m

22 Tues. Subcommittee on Service Committees and Tribunal Regulations, 2 p.m.

23 Wed. Central Ethical Committee, 11 a.m.

23 Wed. Obstetrics Subcommittee (C.C. and S. Committee), 11

25 Fri. Medico-Legal Subcommittee (C.C. and S. Committee), 10 a.m.

25 Fri. Public Health Committee, 10 a.m

25 Fri. Staff Side, Committee C, Medical Whitley Council, 2 p.m.

\section{Branch and Division Meetings to be Held}

Aberystwyth Division.-At Belle Vue Royal Hotel, Saturday, 19 February, 7 for 7.30 p.m., annual dinner dance. Guests are invi:ed. ARMAGH AND WEST Down DIvision.-At Banbridge Hospital, Tuesday, 15 February, 8 p.m., clinical meeting.

Ashton-Under-Lyne Division.- At Canteen, Ashton General Hospital, Wednesday, 16 February, 9 p.m., B.M.A. Lecture by Dr. A. pital, Wednesday, 16 February, 9 p.m., B.M.A. Lecture ,"

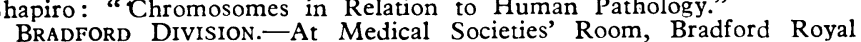
BRADFORD DIVISION.-At Medical Societies' Room, Bradford Royal
Infirmary, Tuesday, is February, 8.15 p.m., jointly with Bradford Infirmary, Tuesday, 15 February, 8.15 p.m., jointly with Bradford Immigration."

BRISTOL Division.-At Large Lecture Theatre, Bristol University Medical School, Friday, 18 February, 8.30 p.m., Mr. P. Rahtz: "Grave Excavations" (illustrated). (Preceded by informal supper, 7 p.m., at University Refectory.)

Buckinghamshire Division.-At Bulls Head Hotel, Aylesbury, Friday, 18 February, 8 for 8.30 p.m., jointly with B.D.A., dinner and dance.

City DIvision.-At Committee Room D, B.M.A. House, Tavistock City Drvision.-At Committee Room D, B.M.A. House, Tavistock
Square, London W.C., Tuesday, 15 February, 8.30 p.m., debate: "This Square, London W.C., Tuesday, 15 February, 8.30 p.m., debate : This
House Believes that there is No Place Whatsoever for Merit or Distinction House Believes that there is No Place Whatsoever for Merit or Distinction
Awards in General Practice at the Present Time." For, Dr. W. R. Awards in General Practice at the Present Time." For, Dr. W. R.
Davies, M.P., and Dr. D. St. J. Murphy. Against, Dr. G. I. Watson and Dr. P. Hopkins. A special meeting to elect Representatives to the Annual Representative Meeting will follow.

DEwsBury Division. - At the Board Room, Dewsbury General Hospital, Friday, 18 "February, "The Medical Care of Students on Hazardous Expeditions."

DorSet Divisinn.-At Casterbridge Lounge, King's Arms Hotel, Dorchester, Friday, 18 February, 8.30 p.m., Mr. R. C. Shepherd: "Reconstructive Arterial Surgery."

Essex Branch.-At Medical Academic Unit, Chelmsford and Essex Hospital, Saturday, 19 February, 3 p.m., annual general meeting and talk by Dr. D. L. Gullick (Under Secretary, B.M.A.); 5 p.m., B.M.A Lecture by Mr. S. Bragg: "Medical Aspects of Planning." A wine and cheese party will follow.

Glasgow Division.-At Grand Hotel, Saturday, 19 February, 3.30 p.m., films : (1) "Glaucoma-Diagnosis and Treatment"; (2) "The English Disease." Discussion will follow.

GREENWICH AND DEPTPORD Division.-At St. Alfege's Hospital, Wednesday, 16 Fehruary, 8.30 for 9 p.m., Dr. G. K. Shaw: "Alcoholism." Grimsby Division.- At Royal Hotel, Thursday, 17 Fehruary, 8 for GrimsBy Drvision. "At Royal Hotel, Thursday, 17 February, 8 for
8.30 p.m., films: (1) "Essentials of a Neurological Examination"; (2) " 8.30 p.m., films: (1) "Essentials of a Neurological Exan

"Triumph of Childhirth." Followed by buffet sunner. 7.30 for 8 p.m., annual dinner. Sir Richard Nugent, M.P., will speak on a sub;ect of general interest. Guests are invited.
LeIGH Division.- At Waterfields Restaurant, Monday, 14 February, 7.45 for 8.15 p.m., medical dinner.

MAIDSTONE Division.-At Willesborough Hospital, Friday, 18 February, 8 for 8.30 p.m., general meeting to discuss emergency medical service ; clinical meeting. Dr. M. H. K. Haggie: " Neonatal Emergencies." NoRTH OF ENGLAND BRANCH.-At Royal Victoria Infirmary, Newcastle
upon Tyne, Thursday, 17 February, 8.30 p.m., jointly with North of upon Tyne, Thursday, 17 February, 8.30 p.m., jointly with North of
England Medico-Legal Society, symposium by Professor D. W. Elliott, Dr. R. Crton: "Sexual Deviations."

NORTH-EAST UlSTER Division.-At Imperial Hotel, Garvagh, Tuesday, 15 February, 8 p.m., (1) Mr. C. G. Irwin : "Obstetric Service in a Rural Area"; (2) film by Dr. J. Hanna: "Vaginal Hysterectomy."

NorTH MIDDI ESEX Division.- At Committee Room, North Middlesex Hospital, Tuesday, 15 February, 8.30 p.m., discussion on B.M.A. Subject of the Year: "Problems of Retirement." Speakers, Dr. H. M. Hodkinson, Dr. J. L. Patton.

READING Division.-At Library, Royal Berkshire Hospital, Monday, 14 February, 8.30 p.m., Dr. P. J. O'Connor: "Echoencephalography" (illustrated).

REDBRIDGE Division.-At King George Hospital, Tuesday, 15 February, 8.45 p.m., jointiy with Ilford Medical Society, Dr. W. W. Sargant: Mechanism of Brainwashing and Conversion."

REIGATE Division.-At Out-patient Hall, Redhill General Hospital Tuesday, 15 February, 8.30 p.m., Dr. A. V. Livingstone: "E.C.G.s and Heart Disease."

Richmond Division.-(1) At Lecture Theatre, West Middlesex Hospital, Tuesday, 15 February, 8.15 for 8.30 p.m., Dr. I. McLean Baird: "Diagnosis and Management of Anaemia." (2) At Reception Room Watney's Brewery, Friday, 18 February, 8.45 p.m., Dr. H. C. Churchill Davidson: "Recent Advances in Anaesthesia."

Rochdale Division.-At Crimble Hotel, Bamford, Rochdale, Monday 14 Fehruary. 8.45 p.m., Professor Peter Bromley, M.A.: "Marriage and Divorce." Wives and guests are invited.

Rotherham Division.-At Steel, Peech, and Tozer's Dining Rooms, Thursday, 17 February, 8 for 8.30 p.m., annual dinner dance.

SHROPSHIRE AND MID-WAI.ES BRANCH.-At Oak Hotel, Shelton, Shrewsbury, Wednesday, 16 February, 8.30 p.m., joint meeting with B.D.A., Dr. D. Robb and Mr. A. H. R. Rowe: "The Things They Do." Guests are invited.

Southampton Division.-At Assembly Hall, Southampton General Hospital, Wednesday, 16 February, 8.15 for 8.30 p.m., Dr. Donald Hunter: "The Art of Diagnosis."

SOUTH RENFORNSHIRE DIVISION.-At Recreation Room, St. Mary's Hospital, Luton, Wednesday, 16 February, 9 p.m., B.M.A. Lecture by Mr. J. H. Lees Ferouson: "Common Surgical Problems in General Practice." Followed by special meeting to consider adoption of revised ethical rules.

STIRI.ING BRanch.-At Mathieson's Rooms, Falkirk, Saturday, 19 February, social evening.

StratFord Division.-At Board Room. East Ham Memorial Hospital Tuesday, 15 February, 9.30 p.m., general meeting to consider adoption of revised ethical rules.

WEST RROMwich and SMEThwick Division.-At Sandwell Hotel, High Street, West Rromwirh, Thursday, 17 February. 8 for 8.15 p.m., supper meeting, Dr. W. J. Walkden: "Coronary Arteries."

Corrections.-Dr. T. McL. Galloway states that he was mistaken in telling the Public Health Committee (Supplement, 8 January, p. 7) that the British Housewives' League was represented at a recent meeting arranoed by the Central Council for Health Education to discuss the fluoridation of woter supplies. Dr. Galloway thought a representative of another organization was a representative of the British Housewives' League, and he apologizes for any embarrassment he may have caused.

The Consumers' Association also states that it was not among the bodies renresented at the meeting arranged by the Central Council for Health Education to discuss fluoridation of water supplies.

The number of general practitioners in England and Wales decreased by 130 between 1 July and 30 September 1965 and not between 1 October and 31 Decemher 1965, as stated in the report of the G.M.S. Committee meeting (Supplement, 5 February, p. 27). 